\title{
EVALUATION OF ANTIMICROBIAL AND ANTIOXIDANT ACTIVITY OF ISOLATED CONSTITUENTS FROM AREAL PART OF CUSCUTA REFLEXA ROXB. PLANT
}

\author{
SANDEEP ${ }^{1 *}$, ABHILASHA MITTAL ${ }^{2}$ \\ ${ }^{1}$ Department of Pharmacognosy, Jayoti Vidyapeeth Women's University, Jaipur - 303 122, Rajasthan, India. ${ }^{2}$ Faculty of Pharmaceutical \\ Science, Jayoti Vidyapeeth Women's University, Jaipur - 303122, Rajasthan, India. Email: sandeepandcp@gmail.com
}

Received: 09 September 2017, Revised and Accepted: 25 November 2017

\section{ABSTRACT}

Objective: The objective of the study was to investigate the pharmacological evaluation of previously isolated compounds (CR-1 to CR-5) from the areal part of Cuscuta reflexa Roxb. is reported.

Methods: The antimicrobial and antioxidant activity of the isolated compounds (CR-1 to CR-5) from C. reflexa was determined by the disc-diffusion method and 1,1-diphenyl-2-picryl-hydrazyl (DPPH) model, respectively. The antimicrobial activity was performed against four strains Staphylococcus aureus, Bacillus subtilis, Escherichia coli, and Pseudomonas aeruginosa.

Results: The results revealed that highest zone of inhibition is measured by compound CR- 5 against $E$. coli. The antioxidant activity is evaluated for in vitro antioxidant activity using DPPH radical scavenging activity, inhibitory concentration $50 \%\left(\mathrm{IC}_{50}\right)(120.92-76.38 \%$ ), respectively. The results indicate that isolated compound CR-1 and CR-2 having IC $_{50} 76.38$ and $76.94 \mu \mathrm{g} / \mathrm{ml}$, respectively, showed potent antioxidant activity comparable to standard ascorbic acid ( $\left.\mathrm{IC}_{50} 43.42 \mu \mathrm{g} / \mathrm{ml}\right)$.

Conclusion: This study suggests that areal part of $C$. reflexa have bioactive compounds for a new antimicrobial and antioxidant drug development.

Keywords: Cuscuta reflexa Roxb., Antimicrobial activity, In vitro antioxidant activity.

(c) 2018 The Authors. Published by Innovare Academic Sciences Pvt Ltd. This is an open access article under the CC BY license (http://creativecommons. org/licenses/by/4. 0/) DOI: http://dx.doi.org/10.22159/ajpcr.2018.v11i3.22475

\section{INTRODUCTION}

Cuscuta reflexa is generally called as dodder plant, otherwise called, witch's hair, devil's hair, and amarbel. Cuscuta belongs to the Cuscutaceae family and on the premise of Angiosperm phylogeny gather it is recognized as having a place with family, Convolvulaceae [1,2]. Dodder plant can similarly pick a fitting host between various plants on the preface of erratic blends release by the host plant as their ordinary technique of transpiration $[3,4]$. Cuscuta makes haustorial relationship with the vascular tissue of the host plant. This haustorium can invade the xylem and phloem of the host plant and associated with tissues of the host plant [5]. C. reflexa contrasts in the shade of flowers made from white to pink. Flowers generally made in the late spring and collect time also depend on the species. Seeds are made in the far-reaching sums. Seeds of $C$. reflexa can get by in the soil for quite a while in the chase of appropriate host, starting at now it depends on the sustenance spare in endosperm of the seed [6].

Distinctive parts of this plant are used as a piece of tribal medication for the disease such as antibacterial [7], antiepileptic [8], antitumor activity [9], and anti-inflammatory [10]. As our previous study, phytochemical investigation of the areal part of C. reflexa Roxb. yields five phytoconstituents, namely, 2,3-dihydro-3,5,7-trihydroxy2-(3-hydroxy-4methoxyphenyl)chromen-4-one (CR-1), 2,3-dihydro3,7dihydroxy-2-(3,4dihydroxyphenyl) chromen-4-one (CR-2) and 6-methoxy-2H-chromen-2-one (CR-3), N-(4-methoxyphenethyl)-3(3,4dihydroxyphenyl)acrylamide (CR-4), and N-(4-butylphenethyl)3-(4-hydroxy-3-methoxyphenyl)acrylamide (CR-5) [11]. The present investigation of chemical constituents of $C$. reflexa was undertaken as part of a wider study to find out the pharmacological active constituents present in this plant. Hence, in the current study, we describe the pharmacological evaluation of previously isolated compounds (CR1-CR5) from the areal part of C. reflexa Roxb. is reported.

\section{METHODS}

The areal part of the plant was collected from the herbal garden of A. N. D. College of Pharmacy, Babhnan, Gonda, Uttar Pradesh, India, in the month of December and identified by an expert taxonomist in the Department of Taxonomy and Pharmacognosy, National Botanical Research Institute, Lucknow. The plant specimens were authenticated (Ref. No NBRI/ CIF $/ 413 / 2013)$. The areal part of the plant was shade dried, reduced to coarse powder and stored in an airtight container till further use. The extraction and isolation were carried out our previous work [11]

\section{Test microorganisms used in the study}

The bacterial strains are identified strains and procured from Scientific and Applied Research Center, India, for antimicrobial susceptibility testing. The microorganisms are Staphylococcus aureus (SA/221-14), Bacillus subtilis (BS/222-14), Escherichia coli (EC/223-14), and Pseudomonas aeruginosa (PA/224-14). All strain were maintained preserved on MullerHinton agar slant throughout the antimicrobial study.

\section{Preparation of bacterial suspension}

Colonies of different strains of bacteria (S. aureus, B. subtilis, E. coli, and P. aeruginosa) were transferred to the different fresh nutrient broth in sterile conditions and were incubated at $37^{\circ} \mathrm{C}$ for $24 \mathrm{~h}$. These suspensions were preserved in $250 \mathrm{ml}$ sterile flasks for further use.

\section{Determination of antimicrobial activity}

In vitro antimicrobial activity of the isolated compound of $C$. reflexa was studied by agar cup plate technique. The sterilized media (nutrient agar media for bacteria) were poured into the Petri plates after the medium was solidified; ditch was made into Petri plate with the help of sterile cork borer $(6 \mathrm{~mm})$. The different concentration of compounds as 50 , 100,150 , and $200(\mu \mathrm{g} / \mathrm{ml})$ was made using dimethyl sulfoxide solvent, which was loaded into the respective well and incubated at $37^{\circ} \mathrm{C}$ for $24 \mathrm{~h}$. Penicillin was used as positive control. The experiment was performed 
under aseptic condition [12], inhibition of microbial growth determined by measuring the diameter of inhibition as shown in Table 1-5.

\section{In vitro antioxidant activity}

1,1-diphenyl-2-picryl-hydrazyl (DPPH) method is the most excellent, easiest and commonly used method for testing preliminary free radical-

Table 1: Screening of antimicrobial activity of isolated compound (CR-1)

\begin{tabular}{|c|c|c|c|c|c|}
\hline \multirow[t]{2}{*}{ Species } & \multicolumn{5}{|c|}{$\begin{array}{l}\text { Concentration }(\mu \mathrm{g} / \mathrm{ml}) \text { of isolated } \\
\text { compound }(\mathrm{CR}-1) \text { used with the zone of } \\
\text { inhibition }(\mathrm{mm})\end{array}$} \\
\hline & 50 & 100 & 150 & 200 & $\begin{array}{l}\text { Standard } \\
100 \text { (Penicillin) }\end{array}$ \\
\hline S. aureus & 7.5 & 7.8 & 8.1 & 9.6 & 14.1 \\
\hline B. subtilis & 5.1 & 6.3 & 6.8 & 7.4 & 14.9 \\
\hline E. coli & 6.1 & 7.3 & 8.5 & 9.8 & 16.5 \\
\hline P. aeruginosa & 6.4 & 7.1 & 7.9 & 9.1 & 13.2 \\
\hline
\end{tabular}

S. aureus: Staphylococcus aureus, B. subtilis: Bacillus subtilis, E. coli: Escherichia coli, P. aeruginosa: Pseudomonas aeruginosa

Table 2: Screening of antimicrobial activity of isolated compound (CR-2)

\begin{tabular}{llllll}
\hline Species & \multicolumn{4}{l}{$\begin{array}{l}\text { Concentration }(\mu \mathrm{\mu g} / \mathbf{m l}) \text { of isolated } \\
\text { compound }(\mathbf{C R}-2) \\
\text { inhibition }(\mathbf{m m})\end{array}$} \\
\cline { 2 - 6 } & $\mathbf{5 0}$ & $\mathbf{1 0 0}$ & $\mathbf{1 5 0}$ & $\mathbf{2 0 0}$ & $\begin{array}{l}\text { Standard } \\
\mathbf{1 0 0} \text { (Penicillin) }\end{array}$ \\
\hline S. aureus & + & 6.7 & 8.9 & 10.5 & 14.1 \\
B. subtilis & 7.1 & 9.7 & 11.8 & 13.1 & 14.9 \\
E. coli & + & + & 8.7 & 10.9 & 16.5 \\
P. aeruginosa & + & + & 9.1 & 10.8 & 13.2 \\
\hline S. authe zone of
\end{tabular}

S. aureus: Staphylococcus aureus, B. subtilis: Bacillus subtilis, E. coli: Escherichia coli, P. aeruginosa: Pseudomonas aeruginosa

Table 3: Screening of antimicrobial activity of isolated compound (CR-3)

\begin{tabular}{llllll}
\hline Species & \multicolumn{2}{l}{$\begin{array}{l}\text { Concentration }(\boldsymbol{\mu g} / \mathbf{m l}) \text { of isolated } \\
\text { compound }(\mathbf{C R}-\mathbf{3}) \text { used with the zone of } \\
\text { inhibition }(\mathbf{m m})\end{array}$} \\
\cline { 2 - 6 } & $\mathbf{5 0}$ & $\mathbf{1 0 0}$ & $\mathbf{1 5 0}$ & $\mathbf{2 0 0}$ & $\begin{array}{l}\text { Standard } \\
\mathbf{1 0 0} \text { (Penicillin) }\end{array}$ \\
\hline S. aureus & + & 9.3 & 10.3 & 12.4 & 14.1 \\
B. subtilis & + & 7.6 & 9.1 & 9.8 & 14.9 \\
E. coli & + & 8.2 & 9 & 11.9 & 16.5 \\
P. aeruginosa & 7.1 & 9.1 & 9.9 & 12.6 & 13.2 \\
\hline S. aureus: Staphylococus & & & & & \\
\hline
\end{tabular}

S. aureus: Staphylococcus aureus, B. subtilis: Bacillus subtilis, E. coli: Escherichia coli, P. aeruginosa: Pseudomonas aeruginosa

Table 4: Screening of antimicrobial activity of isolated compound (CR-4)

\begin{tabular}{llllll}
\hline Species & \multicolumn{2}{l}{$\begin{array}{l}\text { Concentration }(\boldsymbol{\mu g} / \mathbf{m l}) \text { of isolated } \\
\text { compound }(\mathbf{C R}-\mathbf{4}) \text { used with the zone of } \\
\text { inhibition }(\mathbf{m m})\end{array}$} \\
\cline { 2 - 6 } & $\mathbf{5 0}$ & $\mathbf{1 0 0}$ & $\mathbf{1 5 0}$ & $\mathbf{2 0 0}$ & $\begin{array}{l}\text { Standard } \\
\mathbf{1 0 0} \text { (Penicillin) }\end{array}$ \\
\hline S. aureus & + & 12 & 12.9 & 13.5 & 14.1 \\
B. subtilis & 12.5 & 12.7 & 13.8 & 14 & 14.9 \\
E. coli & 11.1 & 13.6 & 14.3 & 15.1 & 16.5 \\
P. aeruginosa & 9.8 & 11.8 & 12.3 & 13 & 13.2 \\
\hline S. aureus: Staphylo & & & & \\
\hline
\end{tabular}

S. aureus: Staphylococcus aureus, B. subtilis: Bacillus subtilis, E. coli: Escherichia coli, P. aeruginosa: Pseudomonas aeruginosa scavenging activity [13-15]. DPPH is a stable free radical containing an odd electron in its structure and usually utilized for detection of the radical scavenging activity in chemical analysis. DPPH is known to abstract labile hydrogen [16-18]. DPPH-radical scavenging activity of synthesized compounds (CR-1 to CR-5) was measured in terms of hydrogen donating or radical-scavenging ability using the stable radical DPPH. Solution of DPPH was prepared and was added to all the synthesized compounds (CR-1 to CR-5) at different concentrations (1-1000 mg/ml). $30 \mathrm{~min}$ later, the absorbance was measured at $517 \mathrm{~nm}$. All the analysis was made with the use of an ultravioletvisible spectrophotometer (Shimadzu 1700). Absorbance of various concentrations was taken, and percentage inhibition was calculated. Lower absorbance of the reaction mixture indicates higher free radicalscavenging activity. Ascorbic acid was used as a standard antioxidant. Inhibitory concentration $50 \%\left(\mathrm{IC}_{50}\right)$ value denotes the concentration of sample required to scavenge $50 \%$ of the DPPH free radical Table 6 . IC of all synthesized compounds (CR-1 to CR-5) was determined from $\%$ inhibition $\mathrm{v} / \mathrm{s}$ concentration graph Fig. 1.

The percentage discoloration was calculated as follows: $\mathrm{DPPH}$ radical scavenging activity $(\%)=\left[\mathrm{AC}_{517}-\mathrm{AE}_{517} / \mathrm{AC}_{517}\right] \times 100$ Where; $\mathrm{AC}_{517}$ is absorbance of a DPPH solution without fraction; $\mathrm{AE}_{517}$ is the absorbance of the tested compounds with DPPH.

\section{RESULT}

Antibacterial activity

The in vitro antibacterial activities of various isolated compounds of C. reflexa against the tested bacteria were assessed by the presence or absence of inhibition zone. The isolated compounds exhibited antibacterial activity against various strains (Fig. 2-6). Isolated compounds (CR-4 and CR-5) from C. reflexa revealed great potential

Table 5: Screening of antimicrobial activity of isolated compound (CR-5)

\begin{tabular}{llllll}
\hline Species & \multicolumn{4}{l}{$\begin{array}{l}\text { Concentration }(\boldsymbol{\mu g} / \mathbf{m l}) \text { of isolated } \\
\text { compound (CR-5) used with the zone of } \\
\text { inhibition (mm) }\end{array}$} \\
\cline { 2 - 6 } & $\mathbf{5 0}$ & $\mathbf{1 0 0}$ & $\mathbf{1 5 0}$ & $\mathbf{2 0 0}$ & $\begin{array}{l}\text { Standard } \\
\mathbf{1 0 0} \text { (Penicillin) }\end{array}$ \\
\hline $\begin{array}{l}\text { S. aureus } \\
\text { B. subtilis }\end{array}$ & 10.7 & 11.8 & 12.4 & 13.6 & 14.1 \\
E. coli & 11.4 & 13 & 13.9 & 14 & 14.9 \\
P. aeruginosa & 10 & 11.4 & 12 & 12.9 & 13.2 \\
\hline S. aureus: Staphyl & & & & & 15.9 \\
\hline
\end{tabular}

S. aureus: Staphylococcus aureus, B. subtilis: Bacillus subtilis, E. coli: Escherichia coli, P. aeruginosa: Pseudomonas aeruginosa

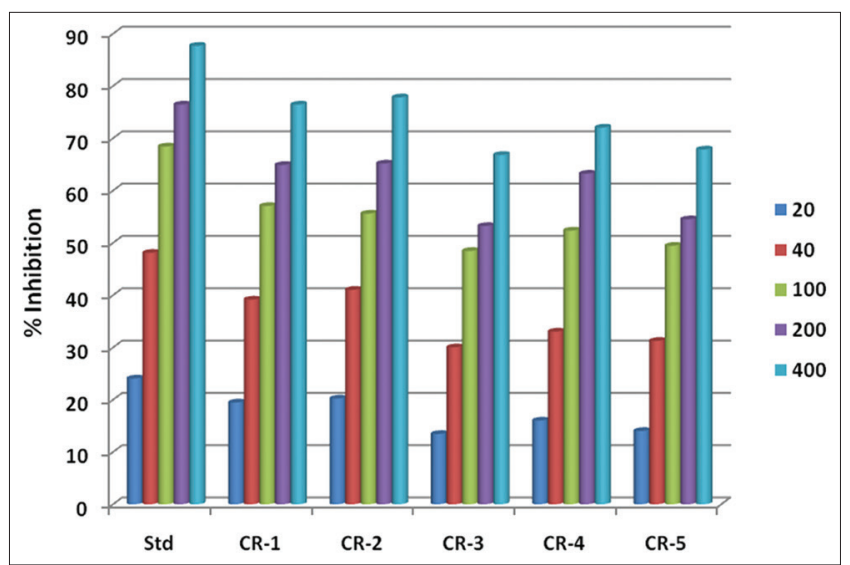

Fig. 1: 1,1-diphenyl-2-picryl-hydrazyl Scavenging assay of isolated compounds from Cuscuta reflexa plant and compared with standard ascorbic acid ( $\%$ of inhibition vs. concentration) of isolated compound (CR-1 to CR-5) 
Table 6: Percentage inhibition of Compounds (CR-1 to CR-5) at various concentrations

\begin{tabular}{|c|c|c|c|c|c|c|c|}
\hline S. No. & Con. $(\mu \mathrm{g} / \mathrm{ml})$ & $\begin{array}{l}\text { Standard (ascorbic } \\
\text { acid) }\end{array}$ & CR-1 & CR-2 & CR- 3 & CR-4 & CR-5 \\
\hline 1 & 20 & $24.04 \pm 0.0376$ & $19.45 \pm 0.1624$ & $20.22 \pm 0.2432$ & $13.44 \pm 0.1243$ & $16.01 \pm 0.1209$ & $14.01 \pm 0.1056$ \\
\hline 2 & 40 & $48.08 \pm 0.1243$ & $39.14 \pm 0.0122$ & $41.01 \pm 0.0266$ & $30.01 \pm 0.2167$ & $33.01 \pm 0.1032$ & $31.24 \pm 0.0043^{*}$ \\
\hline 3 & 100 & $68.41 \pm 0.1821^{* *}$ & $57.04 \pm 0.0244^{* * *}$ & $55.58 \pm 0.1623^{* *}$ & $48.44 \pm 0.2134$ & $52.33 \pm 0.1084^{*}$ & $49.44 \pm 0.0344$ \\
\hline 4 & 200 & $76.44 \pm 0.2172^{* * *}$ & $64.88 \pm 0.2442$ & $65.15 \pm 0.0273$ & $53.22 \pm 0.1004^{*}$ & $63.23 \pm 0.0234$ & $54.49 \pm 0.1044$ \\
\hline 5 & 400 & $87.66 \pm 0.1282$ & $76.44 \pm 0.0244^{* * *}$ & $77.81 \pm 0.1332^{* * *}$ & $66.81 \pm 0.2137$ & $72.04 \pm 0.1034$ & $67.85 \pm 0.1087$ \\
\hline 6 & IC50 & $43.42 \pm 0.2201$ & $76.38 \pm 0.1422^{* *}$ & $76.94 \pm 0.1637^{* *}$ & $120.92 \pm 0.1108^{* * *}$ & $92.66 \pm 0.1088^{*}$ & $111.08 \pm 0.1023$ \\
\hline
\end{tabular}

Data represent mean \pm S.E.M. Of triplicate analysis, $\mathrm{p}^{*}<0.05$ compared to control. SEM: Standard error of the mean

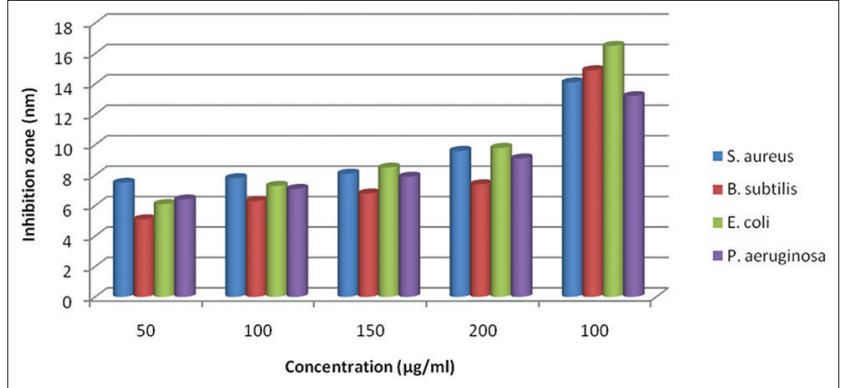

Fig. 2: Diameter of inhibition zone on the growth of different bacterial species due to the application of different concentration of isolated compound (CR-1)

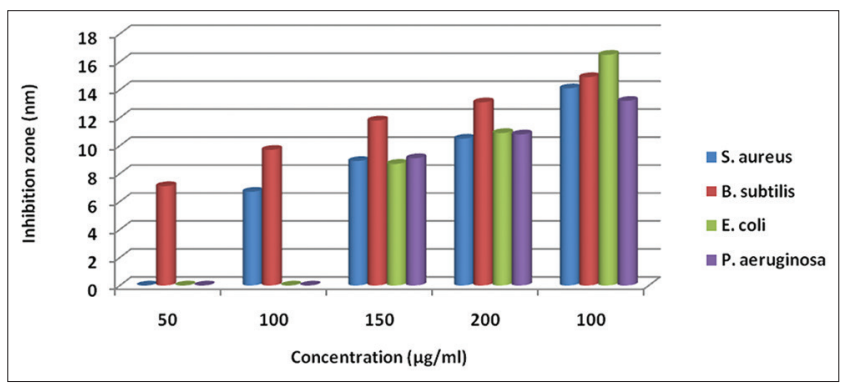

Fig. 3: Diameter of inhibition zone on the growth of different bacterial species due to the application of different concentration of isolated compound (CR-2)

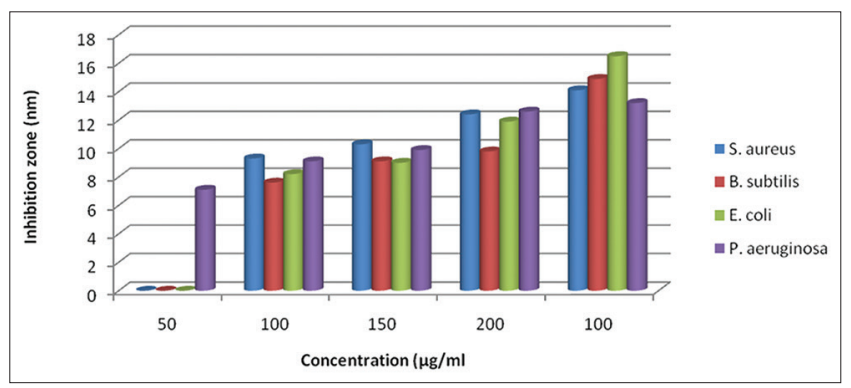

Fig. 4: Diameter of inhibition zone on the growth of different bacterial species due to the application of different concentration of isolated compound (CR-3)

of antibacterial activity against all bacteria (zone ranging from 9 to $15 \mathrm{~mm}$ ) (Fig. 3 and 4). The highest zone of inhibition is measured by compound CR-5 against E. coli (15.9 nm). Compound CR-3 and CR-4 showed moderate antibacterial activity against E. coli and B. sublitis. Compound CR-3 also showed moderate activity against $P$. aeruginosa.

DPPH-scavenging activity

Fig. 6 illustrates a significant decrease in the concentration of DPPH radical due to scavenging ability of the isolated compounds. These

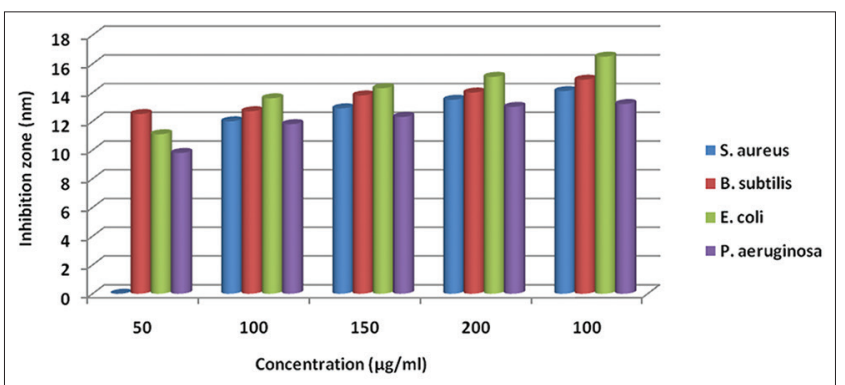

Fig. 5: Diameter of inhibition zone on the growth of different bacterial species due to the application of different concentration of isolated compound (CR-4)

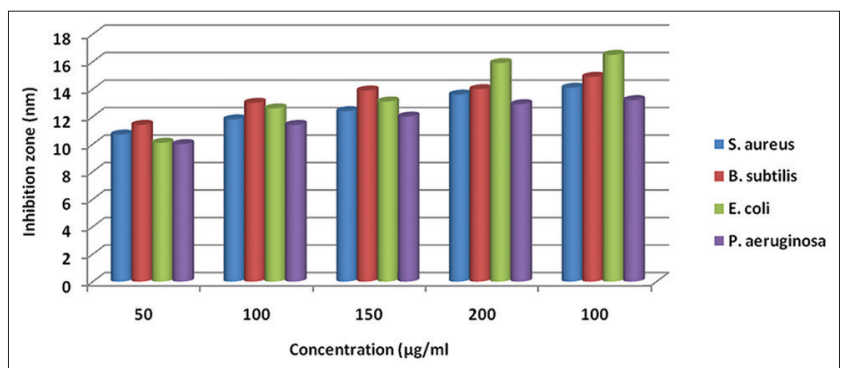

Fig. 6: Diameter of inhibition zone on the growth of different bacterial species due to the application of different concentration of isolated compound (CR-5)

results indicate that the isolated compounds from Cuscuta reflexa (CR-1 and CR-2) plant exhibited more antioxidant activity than the other. It may be due to the presence of $\mathrm{OH}$ groups, which enhance the radical scavenging activity by hydrogen donation. The results indicate that compound CR- 1 and CR- 2 having $\mathrm{IC}_{50} 76.38 \pm 0.14$ and $76.94 \pm 0.16 \mu \mathrm{g} / \mathrm{ml}$ showed potent antioxidant activity comparable to standard ascorbic acid $\left(\mathrm{IC}_{50} 43.42 \pm 0.22 \mu \mathrm{g} / \mathrm{ml}\right)$ as shown in Table 6. The isolated compounds have shown good antioxidant effect, among CR-1 and CR-2 has shown excellent activity. Rest of the compounds (CR-3 to CR-5) showed mild-to-moderate antioxidant effect.

\section{CONCLUSION}

Due to the extremely increasing of the antibiotic unwilling pathogen, it has become predictable to find out the new drugs in pharmaceutical industries. The previous study demonstrated that extracts of C. reflexa showed antibacterial activity against various microorganisms. The result of the current study is relentless with previous studies [19-22]. This study showed the various compounds isolated from C. reflexa plant exhibited great potential inhibitory effect against the tested bacteria. Subsequently, in biological screening, the compounds (CR-1 and CR-2) showed potent antioxidant agent as compared to other isolated compounds. Further research on these plants core is needed for the discovery of a potent antioxidant agent. This study is a preliminary step which indicates the furthermore study is necessary to investigate the 
toxicology and other pharmacological profile of this plant constituent for development of new antibacterial and antioxidant drugs. Thus, we observed that there is enough scope for further study in developing such compounds as a good lead molecule with the better pharmacological profile.

\section{ACKNOWLEDGMENTS}

Authors would like to thank the management of Acharya Narendra Deo College of Pharmacy, Babhnan, Gonda, Uttar Pradesh, for providing research facilities.

\section{REFERENCES}

1. Kirtikar KR, Basu BD. Indian Medicinal Plants. Dehradun, India: International Book Distributors; 2001. p. 1741

2. Story R. Some plants used by the Bushmen in obtaining food and water. Mem Bot Surv S Afr 1958;30:1-115.

3. Kapoor V, Sharma YP. Host range of Cuscuta reflexa Roxb. in Jammu province of Jammu and Kashmir State, India. Indian J Weed Sci 2008:40:98-100

4. Khory RN. Bombay Materia Medica and their Therapeutics. $2^{\text {nd }}$ ed. New Delhi: Periodical Expert Book Agency; 1986. p. 436-8.

5. Dawson JH, Musselman LJ, Wolswinkel P, Dorr I. Biology and control of Cuscuta. Rev Weed Sci 1994;6:265-317.

6. Sharma S, Hullatti KK, Prasanna SM, Kuppast IJ, Sharma P. Comparative study of Cuscuta reflexa and Cassytha filiformis for diuretic activity. Pharmacogn Res 2009;1:327-30.

7. Ayesha M, Suresh PV, Parwez A. Evaluation of antibacterial activity of Cuscuta reflexa and Abutilon indicum. Int J Pharm Biol Sci 2011;2:355-61

8. Borole SP, Oswal RJ, Antre RV, Kshirsagar SS, Bagul YR. Evaluation of anti-epileptic activity of Cuscuta reflexa Roxb. Biol Chem Sci 2011;2:657-63

9. Dandopani C, Sahu KR, Jha KA, Dwlvedl J. Evaluation of antitumor activity of Cuscuta reflexa Roxb (Cuscutaceae) against ehrlich ascites carcinoma in Swiss albino Mice. Trop J Pharm Res 2011;10:447-54
10. Geetha T, Varalakshmi P. Anti-inflammatory activity of lupeol and lupeol linoleate in rat. Ethanopharmacol 2001;76:77-80

11. Sandeep, Mittal A. Isolation and characterization of constituents from areal part of Cuscuta reflexa Roxb. Adv Bioresour 2017;8:250-4.

12. Bauer AW, Kirby WM, Sherris JC, Turck M. Antibiotic susceptibility testing by a standardized single disk method. Am J Clin Pathol 1966; $45: 493-6$.

13. Yogi B, Murti Y, Pathak D. In-vitro antioxidant activity of column chromatography elutes of different extracts of Calotropis procera (giant milkweed) leaves. J Pharm Res 2011;4:1-3

14. Koleva II, van Beek TA, Linssen JP, de Groot A, Evstatieva LN. Screening of plant extracts for antioxidant activity: A comparative study on three testing methods. Phytochem Anal 2002;13:8-17.

15. Uddin SN, Ali ME, Yesmin MN. Antioxidant and antibacterial activities of Senna tora Roxb. Am J Plant Physiol 2008;3:96-100.

16. Constantin M, Bromont C, Fickat R, Massingham R. Studies on the activity of bepridil as a scavenger of free radicals. Biochem Pharmacol 1990;40:1615-22.

17. Matsubara N, Fuchimoto S, Iwagaki H, Nonaka Y, Kimura T, Kashino H, et al. The possible involvement of free radical scavenging properties in the action of cytokines. Res Community Chem Pathol Pharmacol 1991;71:239-42.

18. Yogi B, Mishra A. Synthesis, characterization and antioxidant evaluation of 2-(2-substituted) naphthalene-1,4-dione derivative. J Pharm Res 2016;10:655-9.

19. Pal DK, Mandal M, Senthilkumar GP, Padhiari A. Antibacterial activity of Cuscuta reflexa stem and Corchorus olitorius seed. Fitoterapia 2006;77:589-91.

20. Inamdar BF, Oswal RJ, Choarage TV, Ganga K. In vitro antimicrobial activity of Cuscuta reflexa ROXB. Int Res J Pharm 2011;2:214-6.

21. Arunodaya HS, Krishna V, Shashikumar R, Girish KK. Antibacterial and antioxidant activities of stem bark essential oil constituents of Litsea glutinosa c. B. Rob. Int J Pharm Pharm Sci 2016;8:258-64.

22. Venkanna B, Uma A, Jayalakshmi L. In vitro total phenolics, flavonoids contents, antioxidant and antimicrobial activites of various solvent extracts from the medicinal plant Physalis minima linn. Int J Pharm Pharm Sci 2017;9:192-8. 